\title{
Effects of insulin-like growth factor-1 on the in vitro maturation of canine oocytes
}

\author{
Akane SATO ${ }^{1,2)}$, Borjigin SARENTONGLAGA ${ }^{1}$, Kazuko OGATA $^{1) \#}$, Mio YAMAGUCHI ${ }^{1) \# \#, ~}$

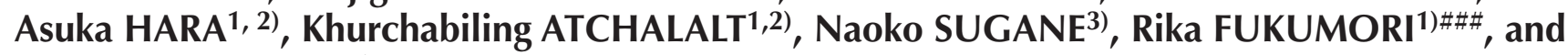 \\ Yoshikazu NAGAO',
}

\author{
1) University Farm, Faculty of Agriculture, Utsunomiya University, Tochigi 321-4415, Japan \\ ${ }^{2)}$ Department of Animal Production Science, United Graduate School of Agricultural Science, Tokyo University of \\ Agriculture and Technology, Tokyo 183-0054, Japan \\ 3) East Japan Guide Dog Association, Tochigi 321-0342, Japan \\ * Present: National Livestock Breeding Center, Fukushima 961-8061, Japan \\ \#\# Present: Local Independent Administrative Agency Hokkaido Research Organization, Hokkaido 081-0038, Japan \\ \#\#\# Present: Rakuno Gakuen University, Hokkaido 069-0836, Japan
}

\begin{abstract}
The maturation rate of canine oocytes during in vitro maturation (IVM) needs to be improved. The present study was designed to evaluate the effects of insulin-like growth factor-1 (IGF-1) on the IVM of canine oocytes. Ovaries were obtained by ovariohysterectomy and were sliced to release cumulus-oocyte complexes (COCs). In Experiment 1, the effects of different concentrations of IGF-1 on the nuclear maturation of oocytes was investigated. The COCs were cultured in a modified medium (mTCM199) with IGF-1 $(0,0.5,5,10$, and $50 \mu \mathrm{g} / \mathrm{ml})$. At the end of the $48 \mathrm{~h}$ culture, oocytes were fixed and stained to evaluate their nuclear stage. Supplementation with $50 \mu \mathrm{g} / \mathrm{ml} \mathrm{IGF-1} \mathrm{induced} \mathrm{a} \mathrm{significantly} \mathrm{higher} \mathrm{metaphase} \mathrm{II}$ (MII) rate $(\mathrm{P}<0.05)$ compared to the 0 and $0.5 \mu \mathrm{g} / \mathrm{ml} \mathrm{IGF-1} \mathrm{groups.} \mathrm{In} \mathrm{Experiment} \mathrm{2,} \mathrm{the} \mathrm{expression} \mathrm{levels} \mathrm{of} \mathrm{insulin} \mathrm{receptor}$ (INSR), IGF-1 receptor $(I G F-1 R)$, and $I G F-2$ receptor $(I G F-2 R)$ genes, localized to canine oocytes and cumulus cells, were investigated before and after IVM. The expression level of $I G F-1 R$ in cumulus cells after IVM was higher than that before IVM $(\mathrm{P}<0.05)$. In Experiment 3, it was investigated whether an inhibitor of PTEN (phosphatase and tensin homolog), bpV, affects the nuclear maturation of oocytes. Regardless of $\mathrm{bpV}$ supplementation at a concentration of 0.2 to $200 \mu \mathrm{mol} / 1$, there was no significant difference in the proportion of oocytes that reached the MII stage. These results indicated that IGF-1 has a favorable effect on the IVM of canine oocytes, possibly through the stimulation of the Ras/MAPK pathway via $I G F-1 R$ expressed in cumulus cells.
\end{abstract}

Key words: bpV, Canine oocyte, Insulin-like growth factor-1 (IGF-1), Insulin-like growth factor-1 receptor (IGF-1R), In vitro maturation

(J. Reprod. Dev. 64: 83-88, 2018)

$\mathbf{T}$ he in vitro maturation (IVM) technique can be applied to various assisted reproductive technologies (ART), such as in vitro fertilization, the microinjection of sperm or DNA into an oocyte, or the cryopreservation of embryos and the generation of cloned animals [1]. ART procedures are also used in canine species, to preserve endangered species [2] and to create efficient breeding systems for working dogs [3]. In many mammalian species, the maturation rate of oocytes during IVM (80\% in humans [4]; $80 \%$ in mice [5]; $90 \%$ in bovine species [6]) is much higher than that in canine species ( 0 to $39.5 \%$ [7-11]). In bovine oocytes, nuclear maturation has been shown to complete after 21 to $24 \mathrm{~h}$ in culture

Received: November 6, 2017

Accepted: November 21, 2017

Published online in J-STAGE: December 7, 2017

(C)2018 by the Society for Reproduction and Development

Correspondence: Y Nagao (e-mail: ynagao@cc.utsunomiya-u.ac.jp)

This is an open-access article distributed under the terms of the Creative Commons Attribution Non-Commercial No Derivatives (by-nc-nd) License. (CC-BY-NC-ND 4.0: https://creativecommons.org/licenses/by-nc-nd/4.0/) medium containing follicle-stimulating hormones and $17 \beta$-estradiol in $5 \% \mathrm{CO}_{2}$ in air [12]. In mouse and human oocytes, the proportion of oocytes that reach metaphase II (MII) after IVM is around 80 to $90 \%[13,14]$. Since the maturation rate of canine oocytes in vitro remains extremely low, many studies have already begun to address this problem by investigating the influence of various IVM conditions, such as co-culture with oviductal epithelial cells [7], the type of culture medium [8], and supplementation of the maturation media with serum, pyruvate, glutamine, and hormones [9-11].

Some growth factors have been shown to promote oocyte maturation in many mammalian species $[15,16]$. It has been demonstrated that insulin-like growth factor-1 (IGF-1) promotes the maturation of bovine oocytes and swelling of cumulus cells [17], and can also inhibit apoptosis [18]. It has also been shown that IGF-1 improves in vitro oocyte maturation, fertilization, and embryo development to the blastocyst stage in mice [19]. The addition of IGF-1 to IVM medium also increased the maturation rate, and improved IVF results in a porcine model [20]. Activation of the $I G F-1$ receptor $(I G F-1 R)$ can result in cell signaling via two pathways: the Ras/mitogen activated 
protein kinase (MAPK) pathway and the phosphoinositide 3-kinase (PI3K)/Akt pathway [21]. The $I G F-1 R$ activates the insulin receptor substrate (IRS) protein, and Src and collagen homologues protein, stimulates Ras through a GTPase, and triggers a kinase cascade, eventually resulting in the activation of MAPK. Otherwise, $I G F-1 R$ is activated through phosphorylation, and subsequently phosphorylates insulin receptor substrate 1 (IRS-1). Activated PI3K then leads to increased levels of phosphatidylinositol 3, 4, 5-trisphosphate (PIP3), which results in the activation of the critical protein Akt/ $\mathrm{PKB}$ through phosphorylation [22]. PI3K is thought to participate in the meiotic maturation of oocytes [23]. The phosphatase and tensin homolog (PTEN) inhibits the action of PI3K by dephosphorylating the signaling lipid PIP3 [24]. A bisperoxovanadium inhibitor of the PTEN [25], bpV, has been shown to regulate cell survival signaling through the PI3K/Akt pathway.

The present study was designed to evaluate the influence of IGF1 supplementation during IVM on canine oocyte maturation. In Experiment 1, different concentrations of IGF-1 were supplemented to an IVM medium, and the nuclear configuration of the oocytes was evaluated after $48 \mathrm{~h}$ of IVM culture. In Experiment 2, the expression levels of insulin receptor (INSR), IGF-1 receptor $(I G F-1 R)$, and $I G F-2$ receptor $(I G F-2 R)$ were investigated in cumulus cells and oocytes before and after IVM by quantitative reverse transcription polymerase chain reaction (RT-qPCR) assay. In Experiment 3, it was investigated whether an inhibitor of PTEN (bpV) supplemented to the IVM medium affected the nuclear maturation of the oocytes.

\section{Materials and Methods}

\section{Collection of ovaries and immature oocytes}

This study was conducted in accordance with the Utsunomiya University Guide for Experimental Animals, under an experimental design approved by the Animal Care and Use Committee of Utsunomiya University. Ovaries were obtained from female dogs (bitches) following routine contraceptive operations at a local veterinary hospital, and were stocked in hygienic plastic bags and transported to the laboratory at room temperature within $6 \mathrm{~h}$ after the operation. The dogs involved in this study were either pure or crossbred, ranged from 6 months to 9 years in age, and were at different stages of estrus.

Cumulus oocyte complexes (COCs) were collected from the ovaries by repeatedly slicing the ovarian cortex with a scalpel blade in Medium 199 (No. 12340, Thermo Fisher Scientific, Waltham, MA, USA) containing $0.1 \%$ (w/v) polyvinyl alcohol (No. 341584, MilliporeSigma, St Louis, MO, USA), $0.5 \mathrm{mM}$ sodium pyruvate (No. 29806-54, Nacalai Tesque, Kyoto, Japan) and 1\% (v/v) antibiotic/ antimycotic agent solution (No. 15240062, Thermo Fisher Scientific, Waltham, MA, USA). The medium described above was defined as mTCM199, and was used for the subsequent IVM. Perfectly spherical oocytes that exhibited an even, smooth, and dark pigmented cytoplasm, measured more than $110 \mu \mathrm{m}$ in diameter, and were surrounded by more than three layers of cumulus cells, were selected for IVM.

\section{IVM of canine COCs}

COCs were washed in the mTCM199. In each culture, 10 COCs were introduced into $50 \mu \mathrm{l}$ drops of the mTCM199 covered with mineral oil in culture dishes (Falcon 351007, Becton, Dickinson and Company, Franklin Lakes, NJ, USA), and were cultured for 48 $\mathrm{h}$ under $5 \% \mathrm{CO}_{2}$ in humidified air at $38.8^{\circ} \mathrm{C}$. In Experiment 1 , the mTCM199 supplemented with $0,0.5,5,10$, or $50 \mu \mathrm{g} / \mathrm{ml}$ of IGF-1 (human, I-3769, MilliporeSigma) was used as the IVM medium. In Experiment 2, the mTCM199 without IGF-1 supplementation was used as the IVM medium. In Experiment 3, the mTCM199 containing $10 \mu \mathrm{g} / \mathrm{ml}$ of IGF-1, to enhance the IGF-1 cascade, was supplemented with $0,0.2,1,5,20,100$, or $200 \mu \mathrm{mol} / 1$ of bpV (HOpic, Calbiochem, 203701, Merck Millipore, Billerica, MA, USA).

\section{Assessment of the meiotic stage}

At the end of the IVM culture, the expansion of cumulus cells was observed under a stereomicroscope (100 ×; Eclipse TE300, Nikon, Tokyo, Japan). The cumulus cells were removed from COCs by gentle pipetting in each $50 \mu 1$ drop of culture medium covered with mineral oil. Denuded oocytes were fixed with Carnoy's solution (99.9\% ethanol: $99.7 \%$ acetic acid in a ratio of $3: 1$ ) for 10 to 30 min. Then, fixed oocytes were washed three times in mTCM199 and stained with phosphate-buffered saline (No. 70011044, Thermo Fisher Scientific) supplemented with $90 \%(\mathrm{v} / \mathrm{v})$ glycerol and $1.9 \mu \mathrm{M}$ Hoechst 33342, on glass slides (SO317, Matsunami, Osaka, Japan). The stained nuclear configuration and chromatin morphology of oocytes were then evaluated under confocal laser scanning microscopy (60 ×; FV10i, Olympus, Tokyo, Japan). The meiotic stage of each oocyte was classified as belonging to one of the following meiotic stages: germinal vesicle (GV), germinal vesicle breakdown (GVBD), metaphase I (MI), and metaphase II (MII), as shown in Fig. 1.

\section{Gene expression analysis}

Oocytes and cumulus cells, obtained pre-IVM and post-IVM, were pooled and frozen at $-196^{\circ} \mathrm{C}$ and then stored at $-80^{\circ} \mathrm{C}$. Subsequently, total RNA was isolated from 20 to 100 denuded oocytes or from 4,000 to 20,000 cumulus cells (approximately 200 cumulus cells per COC) [26] using the PicoPure RNA Isolation Kit (KIT0204, Thermo Fisher Scientific) in accordance with the manufacturer's instructions. The concentration and quality of each RNA sample was determined using a NanoVue system (GE Healthcare, Little Chalfont, UK). Purified RNA samples were incubated in gDNA Wipeout Buffer at $42^{\circ} \mathrm{C}$ for 2 min to remove contaminating genomic DNA, and then the messenger RNA (mRNA) was used for reverse transcription using the QuantiTect Reverse Transcription Kit (No. 205311, QIAGEN, Valencia, CA, USA) in accordance with the manufacturer's instructions. Real-time Polymerase Chain Reaction (PCR) amplifications were performed in a LightCycler 96 (Roche, Basel, Switzerland) using a QuantiTect SYBR Green PCR kit (No. 204143, QIAGEN). Real-time PCR was then performed to determine the relative expression levels of $I N S R$ [27], IGF-IR [28], and IGF-2R [29] by three steps under the following conditions: $95^{\circ} \mathrm{C}$ for $15 \mathrm{~min}$, followed by 45 cycles of $15 \mathrm{sec}$ at $95^{\circ} \mathrm{C}$ for denaturing, $25 \mathrm{sec}$ at $55^{\circ} \mathrm{C}$ for annealing, and 20 sec at $72^{\circ} \mathrm{C}$ for extension. The annealing temperature was optimized for our experimental conditions. To confirm specificity of the product amplification, melting curves were examined. The results of the mRNA expression were normalized to the mRNA expression of glyceraldehyde 3-phosphate dehydrogenase (GAPDH) [30] as an internal control. Primer sequences are shown in Table 1. 

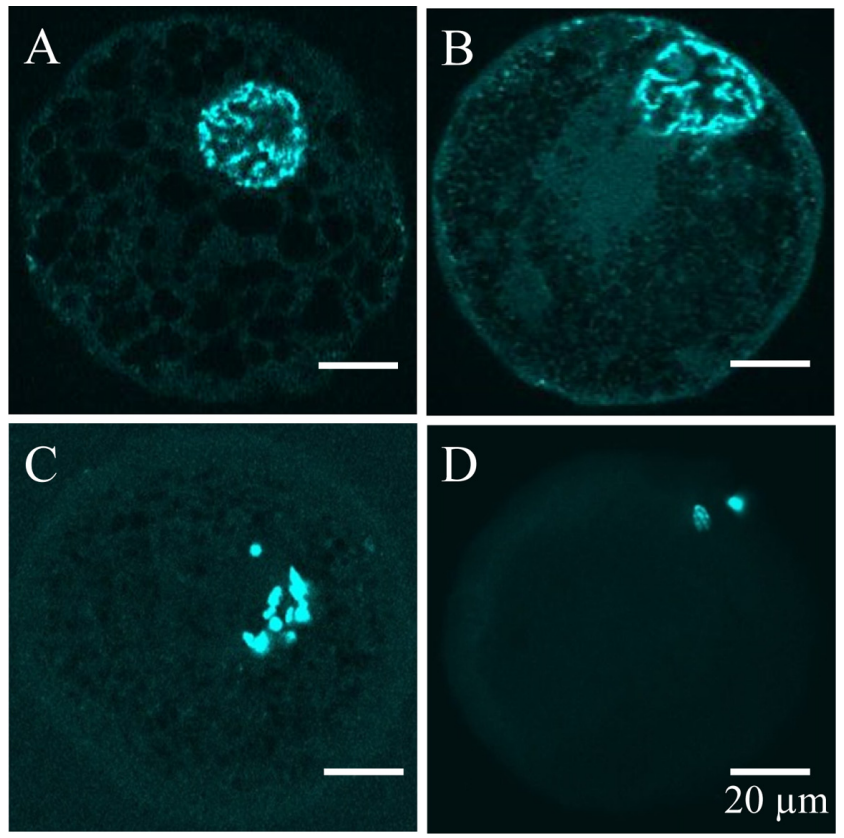

Fig. 1. Chromatin configuration in canine oocytes stained with Hoechst 33342. (A) Oocyte at the germinal vesicle (GV) stage; (B) Oocyte at the germinal vesicle breakdown (GVBD) stage; (C) Oocyte at the metaphase I (MI) stage; (D) Oocyte at the metaphase II (MII) stage. (A), (B) and (C) were single optical sections selected from $\mathrm{Z}$ stacks. (D) was a merged image of $\mathrm{Z}$ stacks.

\section{Statistical analysis}

The proportions of oocytes in each meiotic stage were analyzed using a one-way analysis of variance and the Tukey-Kramer test. In addition, the pre-IVM and post-IVM expression levels of each receptor were tested for normality using the F-test and, if normally distributed, the data were analyzed using a paired $t$-test. Differences at $\mathrm{P}<0.05$ were considered to be statistically significant.

\section{Results}

In Experiment 1, the proportion of MII oocytes in the $50 \mu \mathrm{g} /$ $\mathrm{ml} \mathrm{IGF-1} \mathrm{group} \mathrm{(12.2 \% )} \mathrm{was} \mathrm{significantly} \mathrm{higher} \mathrm{than} \mathrm{those} \mathrm{in} \mathrm{the}$ control $0 \mu \mathrm{g} / \mathrm{ml} \mathrm{IGF-1} \mathrm{group} \mathrm{(2.7 \% )} \mathrm{and} \mathrm{the} 0.5 \mu \mathrm{g} / \mathrm{ml} \mathrm{IGF-1} \mathrm{group}$ (5.3\%; Table 2). The average diameter of COCs before IVM was $126.7 \pm 5.1$, and those after IVM in the $0,0.5,5$, and $50 \mu \mathrm{g} / \mathrm{ml} \mathrm{IGF-1}$ groups were $138.5 \pm 7.4,142.6 \pm 10.5,145.5 \pm 6.2$, and $176.6 \pm 7.3$ $\mu \mathrm{m}$, respectively (Fig. 2).

In Experiment 2, the expression levels of each receptor in the oocytes were not significantly different when compared between preand post-IVM oocytes ( $\mathrm{P}>0.05$; Fig. $3 \mathrm{~A})$. However, the expression level of $I G F-1 R$ in the cumulus cells from post-IVM COCs (1.19 $\pm 0.20)$ was significantly higher $(3.27 \pm 0.64$-fold $)$ than that from pre-IVM COCs $(0.45 \pm 0.09)(\mathrm{P}<0.05$; Fig. 3B). No significant increases were detected in the expression of INSR and IGF-2R during the IVM.

In Experiment 3, an inhibitor of PTEN (bpV) did not affect the nuclear maturation of oocytes regardless of the $\mathrm{bpV}$ supplementation

Table 1. Primers used for the quantitative reverse transcription polymerase chain reaction (RT-qPCR)

\begin{tabular}{clcc}
\hline \multicolumn{1}{c}{ Gene } & \multicolumn{1}{c}{ Primer Sequence $\left(5^{\prime} \rightarrow 3^{\prime}\right)$} & Amplicon $(\mathrm{bp})$ & Reference \\
\hline$I N S R^{\uparrow}$ & $\begin{array}{l}\text { (F) CACCAGTACGTCATCCACAA } \\
\text { (R) GTCTTCTCGCCTTCCAGAAT }\end{array}$ & 136 & {$[27]$} \\
$I G F-1 R^{\star}$ & $\begin{array}{l}\text { (F) CCGACGAGTGGAGAAATCTGT } \\
\text { (R) GGAGGTAGCCCTCGATCACT }\end{array}$ & 99 & {$[28]$} \\
$I G F-2 R^{\S}$ & $\begin{array}{l}\text { (F) GCTCAGCCTGCTGCTGGT } \\
\text { (R) GGATCTCTTCCATCAGCCACTC }\end{array}$ & 196 & {$[29]$} \\
GAPDH $*$ & $\begin{array}{l} \\
\text { (F) TGTCCCCACCCCCAATGTATC }\end{array}$ & 100 & {$[30]$} \\
& (R) CTCCGATGCCTGCTTCACTACCTT & & \\
\hline
\end{tabular}

ף $I N S R$, Insulin receptor; $\$ I G F-I R$, Insulin-like growth factor-1 receptor; ${ }^{\S} I G F-2 R$, Insulin-like growth factor-2 receptor; * GAPDH, Glyceraldehyde 3-phosphate dehydrogenase.

Table 2. The effect of IGF-1 supplementation on the nuclear maturation of canine oocytes

\begin{tabular}{cccccccc}
\hline \multirow{2}{*}{$\begin{array}{c}\text { Concentration of IGF-1 } \\
(\mu \mathrm{g} / \mathrm{ml})\end{array}$} & $\begin{array}{c}\text { No of oocytes } \\
\text { cultured }\end{array}$ & \multicolumn{3}{c}{ Meiotic stage of oocytes (\%) ${ }^{\dagger}$} & & \multirow{2}{*}{ Total } & $\begin{array}{c}\text { No. of oocytes } \\
\text { degenerated }\end{array}$ \\
\cline { 3 - 6 } & 152 & $10(7.2)$ & $52(37.7)$ & $74(53.6)$ & $3(2.2)^{\mathrm{a}}$ & 139 & 13 \\
0 & 97 & $15(16.0)$ & $45(47.9)$ & $29(30.9)$ & $5(5.3)^{\mathrm{a}}$ & 94 & 3 \\
5 & 89 & $7(8.5)$ & $43(52.4)$ & $24(29.3)$ & $8(9.8)^{\mathrm{ab}}$ & 82 & 7 \\
10 & 96 & $6(6.7)$ & $24(26.7)$ & $48(53.3)$ & $12(13.3)^{\mathrm{ab}}$ & 90 & 6 \\
50 & 77 & $11(14.9)$ & $30(40.5)$ & $24(32.4)$ & $9(12.2)^{\mathrm{b}}$ & 74 & 3 \\
\hline
\end{tabular}

$\dagger \%$ : No. of oocytes at each meiotic stage / No. of surviving oocytes. GV, germinal vesicle; GVBD, germinal vesicle breakdown; MI, metaphase I; MII, metaphase II. 

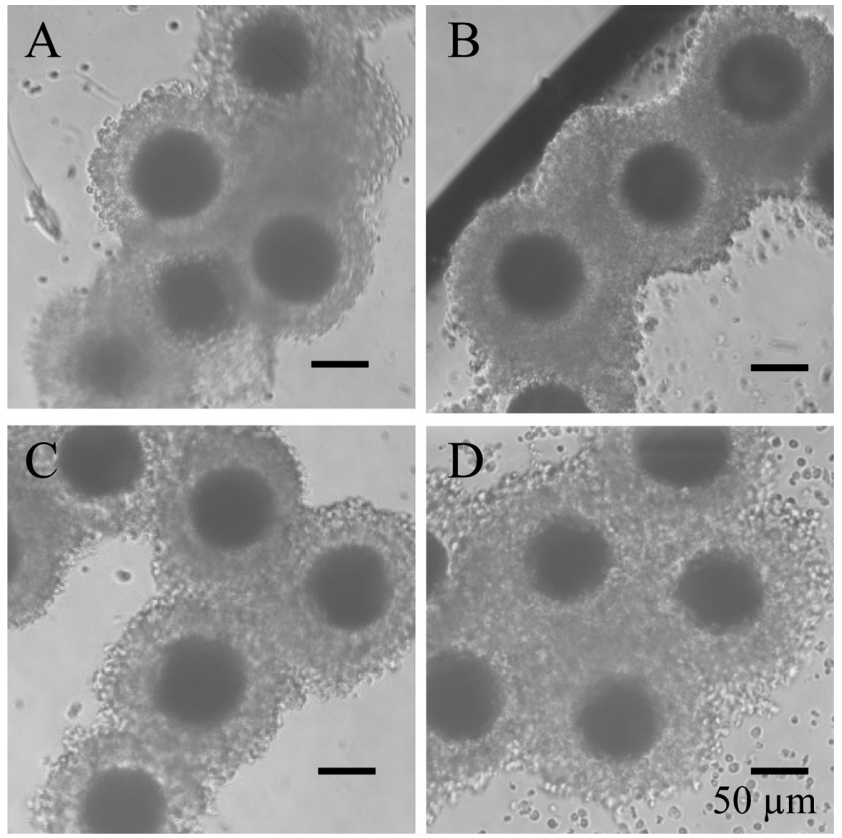

Fig. 2. Morphology of canine COCs after $48 \mathrm{~h}$ of in vitro maturation, showing cumulus cell expansion in the presence of IGF-1. (A) No IGF-1; (B) $0.5 \mu \mathrm{g} / \mathrm{ml} \mathrm{IGF-1;} \mathrm{(C)} 5 \mu \mathrm{g} / \mathrm{ml}$ IGF-1; (D) $50 \mu \mathrm{g} / \mathrm{ml}$ IGF-1.

at 0.2 to $200 \mu \mathrm{mol} / 1(\mathrm{P}>0.05$; Table 3$)$. An increased level of cumulus expansion was not observed after IVM in any of the groups.

\section{Discussion}

IVM procedures for canine oocytes can be applied to preserve endangered species and to create efficient breeding systems for working dogs. However, the maturation rate of canine oocytes in vitro remains extremely low, with studies reporting rates of $16.7 \%$ [7], 33.3\% [8], 14.2\% [9], 39.5\% [10], and 5.5\% [11]. Therefore, the aim of the present study was to improve the efficiency of IVM for canine oocytes. In Experiment 1, we confirmed that supplementation with IGF-1 had a positive effect upon the maturation rate of canine oocytes (Table 2) and cumulus expansion (Fig. 2). It has been shown that IGF-1 affects oocyte maturation in several mammalian species, including mice $(50 \mathrm{ng} / \mathrm{ml})$ [31], cattle $(50 \mathrm{ng} / \mathrm{ml})$ [32], and pigs $(25-200 \mathrm{ng} / \mathrm{ml})$ [33]. In addition, IGF-1 (100 ng/ml) has been shown to stimulate cumulus expansion and enhance nuclear maturation in bovine oocytes [17]. Cumulus expansion could be an index of oocyte maturation, as well as their subsequent developmental ability [34]. These previous studies coincide with our present study indicating that IGF-1 can promote the nuclear maturation of canine oocytes and cumulus expansion, although a high level of IGF-1 $(50 \mu \mathrm{g} / \mathrm{ml})$ is required for the promotion. To our best knowledge, this is the first report to demonstrate the positive impact of IGF-1 supplementation during IVM in the canine species.

Two additional experiments were designed to analyze the possible pathway and mechanism of IGF-1 function in canine IVM. In Experiment 2, we investigated the expression levels of INSR, $I G F-1 R$, and $I G F-2 R$ localized to canine oocytes and cumulus cells before and after IVM. The expression level of $I G F-1 R$ in the cumulus cells isolated from post-IVM COCs was significantly higher than that from pre-IVM COCs (Fig. 3B). The IGF system is composed of two ligands (IGF-1 and IGF-2), two types of receptors (IGF-1R and $I G F-2 R$ ), and six IGF-binding proteins (IGFBPs) [35]. This IGF system has been shown to be expressed in bovine COCs [36]. It was reported that IGF-1R and IGF-2R proteins were detected on the plasma membrane of cumulus cells in immature and mature porcine COCs [37]. However, there are no reports regarding the possible interaction of $I G F-1 R / I G F-2 R$ expression and the nuclear maturation of canine oocytes. It has been shown that cumulus cells can secrete factors such as angiotensin II [38], basic fibroblast growth

\section{(A) Oocytes}

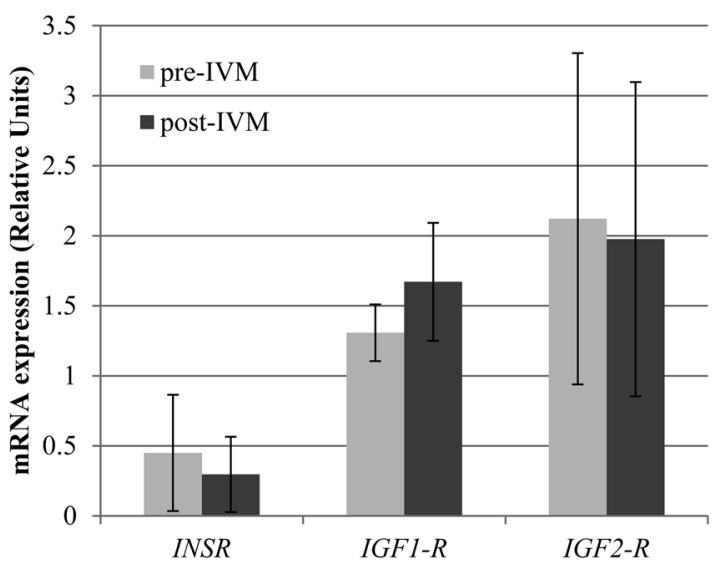

\section{(B) Cumulus cells}

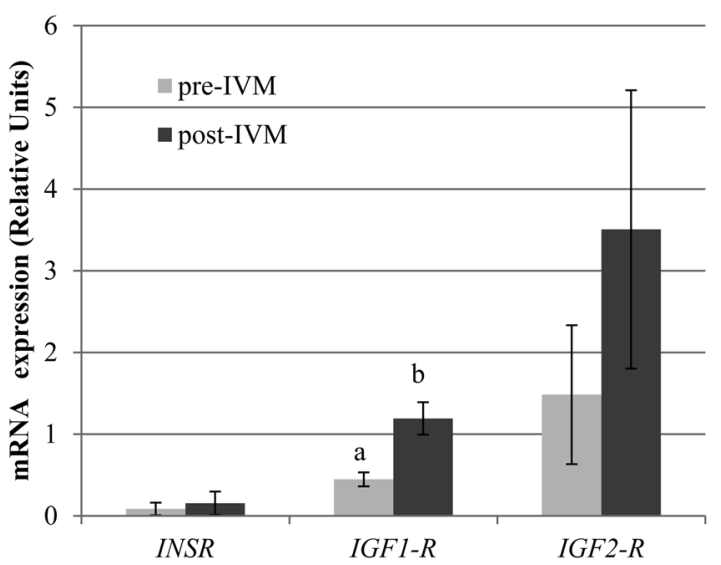

Fig. 3. Relative expression level of mRNA of IGF- $I R, I G F-2 R$, and $I N S R$ in canine oocytes (A) and cumulus cells (B), as detected by quantitative reverse transcription polymerase chain reaction (RT-qPCR) and normalized with glyceraldehyde 3-phosphate dehydrogenase (GAPDH). * IGF$1 R$, Insulin-like growth factor-1 receptor; $I G F-2 R$, Insulin-like growth factor-2 receptor; $I N S R$, Insulin receptor. 
Table 3. The effect of $\mathrm{bpV}$ supplementation on the nuclear maturation of canine oocytes

\begin{tabular}{cccccrrr}
\hline \multirow{2}{*}{$\begin{array}{c}\text { Concentration of bpV } \\
(\mu \mathrm{mol} / \mathrm{l})\end{array}$} & $\begin{array}{c}\text { No of oocytes } \\
\text { cultured }\end{array}$ & \multicolumn{3}{c}{ Meiotic stage of oocytes (\%) ${ }^{\dagger}$} & & \multirow{2}{*}{$\begin{array}{c}\text { Total } \\
\text { No. of oocytes } \\
\text { degenerated }\end{array}$} \\
\cline { 3 - 5 } & 108 & $1(1.0)$ & $41(39.8)$ & $51(49.5)$ & $10(9.7)$ & 103 & 5 \\
0 & 58 & $1(1.8)$ & $26(45.6)$ & $28(49.1)$ & $2(3.5)$ & 57 & 1 \\
1 & 52 & $1(2.0)$ & $23(46.0)$ & $23(46.0)$ & $3(6.0)$ & 50 & 2 \\
5 & 123 & $1(8.2)$ & $55(45.1)$ & $60(49.2)$ & $6(4.9)$ & 122 & 1 \\
20 & 72 & $0(0)$ & $24(33.8)$ & $45(63.3)$ & $2(2.8)$ & 71 & 1 \\
100 & 85 & $0(0)$ & $36(42.9)$ & $38(45.2)$ & $10(11.9)$ & 84 & 1 \\
200 & 65 & $0(0)$ & $32(59.3)$ & $15(27.8)$ & $7(13.0)$ & 54 & 11 \\
\hline
\end{tabular}

$\dagger \%$ : No. of oocytes at each meiotic stage / No. of surviving oocytes. GV, germinal vesicle; GVBD, germinal vesicle breakdown; MI, metaphase I; MII, metaphase II.

factor [39], and estradiol [40]. These factors may increase the level of $I G F-1 R$ expression during maturation. Therefore, the increased $I G F-1 R$ expression in post-IVM cumulus cells detected in the present study suggests the function of the IGF pathway within canine COCs; IGF-1 may function via $I G F-1 R$, which is expressed during the later stages of culture, and promote the meiotic progression of oocytes from the MI to MII stage. In Experiment 3, we investigated whether $\mathrm{bpV}$ supplementation during IVM can improve the nuclear maturation rate of canine oocytes. IGF-1 has been shown to activate two major signal transduction pathways: the PI3K/Akt pathway and the Ras/ MAPK pathway [21]. A bisperoxovanadium inhibitor of PTEN, bpV, [25], has been shown to regulate cell survival signaling through the $\mathrm{PI} 3 \mathrm{~K} /$ Akt pathway. Furthermore, a previous study reported that $\mathrm{bpV}$ can stimulate the growth of isolated non-growing primary oocytes in mice [41]. In the present study, although the expression level of $I G F-1 R$ increased during the later stages of IVM culture, the treatment of canine COCs with bpV (0.2 to $200 \mu \mathrm{mol} / \mathrm{l})$ and IGF-1 $(10 \mu \mathrm{g} / \mathrm{ml})$ did not influence the maturation rate of canine oocytes (Table 3 ). Villa-Diaz et al. indicated that an MAPK inhibitor (SB203580) did not affect GVBD, but it decreased the number of oocytes reaching MII, and conversely increased the number of oocytes arrested at MI in the maturation of porcine oocytes [42]. Activation of MAPK leads to the phosphorylation and activation of specific MAPK-activated protein kinases (MAPKAPKs), such as members of the RSK, MSK, and MNK family, as well as MK2/3/5 [43]. These previous studies and the results of the present study indirectly suggest that nuclear maturation of canine oocytes may be promoted by IGF-1 through the activation of the Ras/MAPK pathway rather than the PI3K/Akt pathway; the Ras/MAPK pathway has been shown to be implicated in the maturation of oocytes in various mammalian species [44].

In conclusion, supplementation of $50 \mu \mathrm{g} / \mathrm{ml} \mathrm{IGF-1} \mathrm{into} \mathrm{IVM}$ medium exerted a positive influence on canine oocytes, with increased maturation to the MII stage. A higher expression level of $I G F-1 R$ after IVM and no effect of $\mathrm{bpV}$ on the promotion of nuclear maturation suggest that IGF-1 may stimulate the Ras/MAPK pathway via increased expression of $I G F-1 R$ in cumulus cells during IVM, and thus promote the maturation of canine oocytes from the MI to MII stage.

\section{References}

1. Mapletoft RJ, Hasler JF. Assisted reproductive technologies in cattle: a review. Rev Sci Tech 2005; 24: 393-403. [Medline] [CrossRef]

2. Farstad W. Current state in biotechnology in canine and feline reproduction. Anim Reprod Sci 2000; 60-61: 375-387. [Medline] [CrossRef]

3. Fuyuno I. Biobank provides leads for selecting guide dogs. Nature 2007; 446: 119. [Medline] [CrossRef]

4. Coticchio G, Dal-Canto M, Guglielmo MC, Mignini-Renzini M, Fadini R. Human oocyte maturation in vitro. Int J Dev Biol 2012; 56: 909-918. [Medline] [CrossRef]

5. Fulka J Jr, Moor RM, Fulka J. Mouse oocyte maturation: meiotic checkpoints. Exp Cell Res 1995; 219: 414-419. [Medline] [CrossRef]

6. Rodrigues-Cunha MC, Mesquita LG, Bressan F, Collado MD, Balieiro JC, Schwarz KR, de Castro FC, Watanabe OY, Watanabe YF, de Alencar Coelho L, Leal CL. Effects of melatonin during IVM in defined medium on oocyte meiosis, oxidative stress, and subsequent embryo development. Theriogenology 2016; 86: 1685-1694. [Medline] [CrossRef]

7. Bogliolo L, Zedda MT, Ledda S, Leoni G, Naitana S, Pau S. Influence of co-culture with oviductal epithelial cells on in vitro maturation of canine oocytes. Reprod Nutr Dev 2002; 42: 265-273. [Medline] [CrossRef]

8. Songsasen N, Yu I, Leibo SP. Nuclear maturation of canine oocytes cultured in proteinfree media. Mol Reprod Dev 2002; 62: 407-415. [Medline] [CrossRef]

9. Oh HJ, Fibrianto YH, Kim MK, Jang G, Hossein MS, Kim HJ, Kang SK, Lee BC, Hwang WS. Effects of canine serum collected from dogs at different estrous cycle stages on in vitro nuclear maturation of canine oocytes. Zygote 2005; 13: 227-232. [Medline] [CrossRef]

10. Songsasen N, Spindler RE, Wildt DE. Requirement for, and patterns of, pyruvate and glutamine metabolism in the domestic dog oocyte in vitro. Mol Reprod Dev 2007; 74: 870-877. [Medline] [CrossRef]

11. Evecen M, Cirit U, Demir K, Hamzaoğlu AI, Bakırer G, Pabuccuoğlu S, Birler S. Adding hormones sequentially could be an effective approach for IVM of dog oocytes. Theriogenology 2011; 75: 1647-1651. [Medline] [CrossRef]

12. Younis AI, Brackett BG, Fayrer-Hosken RA. Influence of serum and hormones on bovine oocyte maturation and fertilization in vitro. Gamete Res 1989; 23: 189-201. [Medline] [CrossRef]

13. Chian RC, Buckett WM, Tan SL. In-vitro maturation of human oocytes. Reprod Biomed Online 2004; 8: 148-166. [Medline] [CrossRef]

14. Kidder BL. In vitro maturation and in vitro fertilization of mouse oocytes and preimplantation embryo culture. Methods Mol Biol 2014; 1150: 191-199. [Medline] [CrossRef]

15. Driancourt MA, Thuel B. Control of oocyte growth and maturation by follicular cells and molecules present in follicular fluid. A review. Reprod Nutr Dev 1998; 38: 345-362. [Medline] [CrossRef]

16. Arat S, Caputcu AT, Cevik M, Akkoc T, Cetinkaya G, Bagis H. Effect of growth factors on oocyte maturation and allocations of inner cell mass and trophectoderm cells of cloned bovine embryos. Zygote 2016; 24: 554-562. [Medline] [CrossRef]

17. Lorenzo PL, Illera MJ, Illera JC, Illera M. Enhancement of cumulus expansion and nuclear maturation during bovine oocyte maturation in vitro by the addition of epidermal growth factor and insulin-like growth factor I. J Reprod Fertil 1994; 101: 697-701. [Medline] [CrossRef]

18. Wasielak M, Bogacki M. Apoptosis inhibition by insulin-like growth factor (IGF)-I during in vitro maturation of bovine oocytes. J Reprod Dev 2007; 53: 419-426. [Medline] [CrossRef] 
19. Toori MA, Mosavi E, Nikseresht M, Barmak MJ, Mahmoudi R. Influence of insulinlike growth factor-I on maturation and fertilization rate of immature oocyte and embryo development in NMRI mouse with TCM199 and alpha-MEM medium. J Clin Diagn Res 2014; 8: AC05-AC08. [Medline]

20. Oberlender G, Murgas LDS, Zangeronimo MG, da Silva AC, Menezes TA, Pontelo TP, Vieira LA. Role of insulin-like growth factor-I and follicular fluid from ovarian follicles with different diameters on porcine oocyte maturation and fertilization in vitro. Theriogenology 2013; 80: 319-327. [Medline] [CrossRef]

21. Murphy CT, Hu PJ. Insulin/insulin-like growth factor signaling in C. elegans. In: WormBook. 2013; Pasadena, USA, 1-43. [Medline] [CrossRef]

22. Blair TA, Moore SF, Williams CM, Poole AW, Vanhaesebroeck B, Hers I. Phosphoinositide 3-kinases $p 110 \alpha$ and p110 $\beta$ have differential roles in insulin-like growth factor-1-mediated Akt phosphorylation and platelet priming. Arterioscler Thromb Vasc Biol 2014; 34: 1681-1688. [Medline] [CrossRef]

23. Hoshino Y, Yokoo M, Yoshida N, Sasada H, Matsumoto H, Sato E. Phosphatidylinositol 3-kinase and Akt participate in the FSH-induced meiotic maturation of mouse oocytes. Mol Reprod Dev 2004; 69: 77-86. [Medline] [CrossRef]

24. Worby CA, Dixon JE. PTEN. Annu Rev Biochem 2014; 83: 641-669. [Medline] [CrossRef]

25. Spinelli L, Lindsay YE, Leslie NR. PTEN inhibitors: an evaluation of current compounds. Adv Biol Regul 2015; 57: 102-111. [Medline] [CrossRef]

26. Kölle S, Woehl-Wenigerkind A, Sinowatz F, Braun J. Regulation of cumulus cell numbers in the course of the canine estrous cycle. Anat Histol Embryol 2005; 34: 26-27.

27. Klopfleisch R, Hvid H, Klose P, da Costa A, Gruber AD. Insulin receptor is expressed in normal canine mammary gland and benign adenomas but decreased in metastatic canine mammary carcinomas similar to human breast cancer. Vet Comp Oncol 2010; 8: 293-301. [Medline] [CrossRef]

28. Maniscalco L, Iussich S, Morello E, Martano M, Gattino F, Miretti S, Biolatti B, Accornero P, Martignani E, Sánchez-Céspedes R, Buracco P, De Maria R. Increased expression of insulin-like growth factor-1 receptor is correlated with worse survival in canine appendicular osteosarcoma. Vet $J 2015 ; 205$ : 272-280. [Medline] [CrossRef]

29. Housley DJ, Ritzert E, Venta PJ. Comparative radiation hybrid map of canine chromosome 1 incorporating SNP and indel polymorphisms. Genomics 2004; 84: 248-264. [Medline] [CrossRef]

30. Mori A, Lee P, Takemitsu H, Sako T, Arai T. Comparison of insulin signaling gene expression in insulin sensitive tissues between cats and dogs. Vet Res Commun 2009; 33: 211-226. [Medline] [CrossRef]

31. Kiapekou E, Loutradis D, Drakakis P, Zapanti E, Mastorakos G, Antsaklis A. Effects of GH and IGF-I on the in vitro maturation of mouse oocytes. Hormones (Athens) 2005; $\mathbf{4}$ : 155-160. [Medline] [CrossRef]

32. Herrler A, Lucas-Hahn A, Niemann H. Effects of insulin-like growth factor-I on invitro production of bovine embryos. Theriogenology 1992; 37: 1213-1224. [CrossRef]

33. Xia P, Tekpetey FR, Armstrong DT. Effect of IGF-I on pig oocyte maturation, fertilization, and early embryonic development in vitro, and on granulosa and cumulus cell biosynthetic activity. Mol Reprod Dev 1994; 38: 373-379. [Medline] [CrossRef]

34. Gliedt DW, Rosenkrans CF Jr, Rorie RW, Munyon AL, Pierson JN, Miller GF, Rakes JM. Effects of media, serum, oviductal cells, and hormones during maturation on bovine embryo development in vitro. J Dairy Sci 1996; 79: 536-542. [Medline] [CrossRef]

35. Pavelić J, Matijević T, Knezević J. Biological \& physiological aspects of action of insulin-like growth factor peptide family. Indian J Med Res 2007; 125: 511-522. [Medline]

36. Wang LM, Feng HL, Ma YZ, Cang M, Li HJ, Yan Z, Zhou P, Wen JX, Bou S, Liu DJ. Expression of IGF receptors and its ligands in bovine oocytes and preimplantation embryos. Anim Reprod Sci 2009; 114: 99-108. [Medline] [CrossRef]

37. Zhu G, Liu S, Jiang Y, Yang H, Li J. Growth hormone pathway gene expression varie in porcine cumulus-oocyte complexes during in vitro maturation. In Vitro Cell Dev Biol Anim 2008; 44: 305-308. [Medline] [CrossRef]

38. Siqueira LC, Barreta MH, Gasperin B, Bohrer R, Santos JT, Buratini J Jr, Oliveira JF, Gonçalves PB. Angiotensin II, progesterone, and prostaglandins are sequentia steps in the pathway to bovine oocyte nuclear maturation. Theriogenology 2012; 77: 1779-1787. [Medline] [CrossRef]

39. Salha O, Abusheikha N, Sharma V. Dynamics of human follicular growth and in-vitro oocyte maturation. Hum Reprod Update 1998; 4: 816-832. [Medline] [CrossRef]

40. Chian RC, Ao A, Clarke HJ, Tulandi T, Tan SL. Production of steroids from human cumulus cells treated with different concentrations of gonadotropins during culture in vitro. Fertil Steril 1999; 71: 61-66. [Medline] [CrossRef]

41. Morohaku K, Hoshino Y, Sasada H, Sato E. Incorporation of phosphatase inhibitor in culture prompts growth initiation of isolated non-growing oocytes. PLOS ONE 2013; 8: e77533. [Medline] [CrossRef]

42. Villa-Diaz LG, Miyano T. Activation of p38 MAPK during porcine oocyte maturation. Biol Reprod 2004; 71: 691-696. [Medline] [CrossRef]

43. Zhang W, Liu HT. MAPK signal pathways in the regulation of cell proliferation in mammalian cells. Cell Res 2002; 12: 9-18. [Medline] [CrossRef]

44. Eckerdt F, Yamamoto TM, Lewellyn AL, Maller JL. Identification of a polo-like kinase 4-dependent pathway for de novo centriole formation. Curr Biol 2011; 21: 428-432. [Medline] [CrossRef] 